have suffered little change since the Polynesian ancestors of the inhabitants first arrived there twenty generations ago. It was also possible to arrange for an intensive study of the disease and general health of the population of one district. Blood samples for filaria tests and blood groups were obtained. On Bellona the party was fortunate enough to obtain cinematograph record of the annual firstfruits ceremony. A medical and health survey was also made on the islands of San Cristobal, Santa Anna and Santa Catalina. As a result of the expedition's work, 3,200 artefacts have been added to the collections of the museum in Honolulu, as well as a large number of entomological and botanical specimens. Other collections are to be distributed among scientific institutions in America and Europe, while the material relating to canoes will be submitted to Dr. A. C. Haddon in Cambridge.

\section{Regulations Concerning Chemicals}

Acrs of Parliament and Statutory Rules and Orders affecting the chemical industry are sufficiently numerous and complex to require documentation in a convenient and easily accessible form. That task has been undertaken by the Association of British Chemical Manufacturers, which in January 1931 published an index of such information. The third supplement, covering acts, rules and orders which have come to the notice of the Association during 1933 has recently been issued (Heffer, Cambridge; $6 d$. post free). New regulations regarding the packing and stowing of dangerous goods in ships have been made, and a revised edition of the summary of the principal regulations made under the Explosives Act has been issued. Reference is made to the Spirits Act, 1880, and the Still Licence Act, 1849. All plant capable of being used as a still is subject to licence, but exemptions are granted in respect of alkali works, coal gas, tar distillation, solvent recovery, chemical experiments, professional chemists, etc. Water stills of more than 1 gallon capacity require a licence; otherwise exemption may be granted on application. The supplementary index also refers, inter alia, to the Dyestuffs (Import Regulation) Act, the Import Duties Act, the Ottawa Agreements Act, the Poisons and Pharmacy Act, and the Safeguarding of Industries Act.

\section{Graph Papers}

WE have received from Messrs. Wightman Mountain, Ltd., of Artillery House, Victoria Street, Westminster, some samples of graph paper. These are of considerable interest as exhibiting the great range and variety of papers now produced in England. Of squared papers alone, Messrs. Wightman Mountain list more than 250 sizes and styles, some with ruled and others with engraved lines. A wide range of logarithmic papers includes, for example, sheets covering the ranges $7-400$ and $1-10,000$. Profile paper is specially ruled for making longitudinal sections of railways, roads, etc. Other varieties of graph paper include permille paper (arithmetic probability), square-law, polar, isocandle, triangular and isometric papers. A new paper is one ruled in tenths of an inch one way and in inches and twelfths the other. The increasing demand for the graphical presentation of commercial data has led to the publication of a number of data sheets, including daily, weekly and monthly progress sheets. Even a holiday chart is not lacking. To furnish some idea of the papers available, the firm is offering for half a crown a special sample packet of 58 different data sheets.

\section{International Agricultural Congress in Budapest}

The International Congress of Agriculture is meeting this year in Budapest on June 13-20. The Congress is held every two years in a different European capital and is attended by delegates from some thirty countries who represent every side of agricultural life. The work of the Congress is divided into eight sections. The first deals with economics and agrarian policy, world prices, the organisation of markets and the economic consequences of mechanisation. Two other sections, those on cooperation and agricultural industries, occupy parts of the same field, and the section dealing with viticulture will this year be economic rather than technical. Two sections treat respectively of animal and vegetable production from the scientific side. Modern horse-breeding, the influence of pasture on the quality of milk, contagious abortion, the production of forage crops under semi-desert conditions, plant selection, the classification of wheats and the improvement of alkaline soils are the principal subjects for discussion at Budapest. The remaining sections are to some extent social in scope, dealing with agricultural instruction and the position of women in rural communities. The Congress will be accompanied by social functions and followed by excursions, which will enable delegates to see something of educational and scientific work in connexion with Hungarian agriculture, as well as of Hungarian farming and peasant life. It is expected that a party of British delegates, connected either with agricultural science or with bodies such as the National Federation of Women's Institutes, will take part. Further information can be obtained from the secretary of the British Corresponding Committee, International Congress of Agriculture, 10 Doughty Street, London, W.C.1.

\section{Announcemerts}

Prof. J. C. McLennan will deliver the twentyfifth Kelvin Lecture before the Institution of Electrical Engineers on April 26, taking as his subject "Electrical Phenomena at Extremely Low Temperatures". Before the lecture, the Faraday Medal of the Institution will be presented to Sir Frank Smith.

Dr. C. E. Kenneth Mees, director of research to the Eastman Kodak Co., Rochester, U.S.A., will deliver the Sir Henry Trueman Wood Memorial Lecture before the Royal Society of Arts on May 16. The subject of Dr. Mees's lecture will be "Some Photographic Aspects of Sound Recording". 